\title{
Socio-Economic and Environmental Impact of Nuclear Desalination
}

\author{
Salah Ud-Din Khan 1,2,*(D) and Jamel Orfi ${ }^{2,3}$ \\ 1 Sustainable Energy Technologies Center, College of Engineering, King Saud University, P.O. Box 800, \\ Riyadh 11421, Saudi Arabia \\ 2 K.A. CARE Energy Research and Innovation Center in Riyadh, P.O. Box 2022, \\ Riyadh 11451, Saudi Arabia; orfij@ksu.edu.sa \\ 3 Mechanical Engineering Department, College of Engineering, King Saud University, P.O. Box 800, \\ Riyadh 11421, Saudi Arabia \\ * Correspondence: drskhan@ksu.edu.sa
}

Citation: Khan, S.U.-D.; Orfi, J. Socio-Economic and Environmental Impact of Nuclear Desalination. Water 2021, 13, 1637. https:// doi.org/10.3390/w13121637

Academic Editor: Licínio

M. Gando-Ferreira

Received: 7 April 2021

Accepted: 7 June 2021

Published: 10 June 2021

Publisher's Note: MDPI stays neutral with regard to jurisdictional claims in published maps and institutional affiliations.

Copyright: (c) 2021 by the authors. Licensee MDPI, Basel, Switzerland. This article is an open access article distributed under the terms and conditions of the Creative Commons Attribution (CC BY) license (https:/ / creativecommons.org/licenses/by/ $4.0 /)$.

\begin{abstract}
Nuclear desalination concept and implementation spanning 50 years are recognized as an economical viable option for water and electricity production but could not receive wider applications. This is due to various factors, in addition to technical design parameters, other factors, such as social, economic, and environmental issues, need to be considered. For this purpose, the current studies start with performing a critical and up-to-date literature review on previous investigations in the field of nuclear reactors and integrated nuclear power with desalination plants with a specific focus on performance criteria, technical specifications, etc. Reviewing and compiling the most updated technical specifications, cost estimations, and environmental data related to nuclear power and desalination plants are also important steps. Previous studies show a special focus on other important issues on nuclear desalination characteristics in countries including Saudi Arabia, Egypt, United Arab Emirates, Pakistan, India, and Kuwait. This work presents a concise review of previous works on the relevancy of other issues, such as economic, environmental, and social, associated with the use of nuclear energy in power generation and fresh water production. Preliminary assessment of possible hybrid configurations of nuclear and desalination technologies is developed and assessed by a computational program. Both operating and capital cost of the integrated plants are calculated. The simulation model is then extended to compare with other heating reactors as well for the verification analysis. The results obtained from comparative assessment depicts the accuracy of the simulation model used for preliminary assessment of the integrated nuclear desalination option. The main objective of the research is to assess the nuclear desalination plant development in terms of social, economic and environmental aspects. The results will pave the way for countries interested in developing nuclear desalination plants.
\end{abstract}

Keywords: nuclear desalination; state-of-the-art literature report; social-economic-environmental model; simulation; validation studies

\section{Introduction}

Nuclear energy is a unique source of power which is environmentally friendly and could effectively replace existing energy sources, such as fossil fuels. Also, the energy produced from nuclear systems is inexhaustible, just like traditional sources known as renewable energy sources, which have lower power production capacity compared to nuclear energy and still need to be developed. There are many types of nuclear power plants, including large and small to medium sized plants, among them the most advanced reactors are the small modular reactors (SMRs) [1]. Figure 1 presents the list of SMRs with their power outputs and status.

The commercial operation of nuclear power plants (total of 440 plants worldwide) practicing in 31 countries, while 60 plants are under construction in 15 countries, including 
China, Russia, South Korea, India, Pakistan, and the United Arab Emirates. The United States generates approximately one third of the world's electricity from nuclear power, while some countries are more dependent on nuclear power, such as France, which produces approximately half of the electricity generated in the USA from nuclear power plants. Presently, it is estimated that $11 \%$ of the global electric energy supply is derived from nuclear energy. All power plants used in the world to generate nuclear power involve the process of nuclear fission. In a nuclear fission process, the amount of energy released per atom is about 1,000,000 times that obtained in fossil fuels.

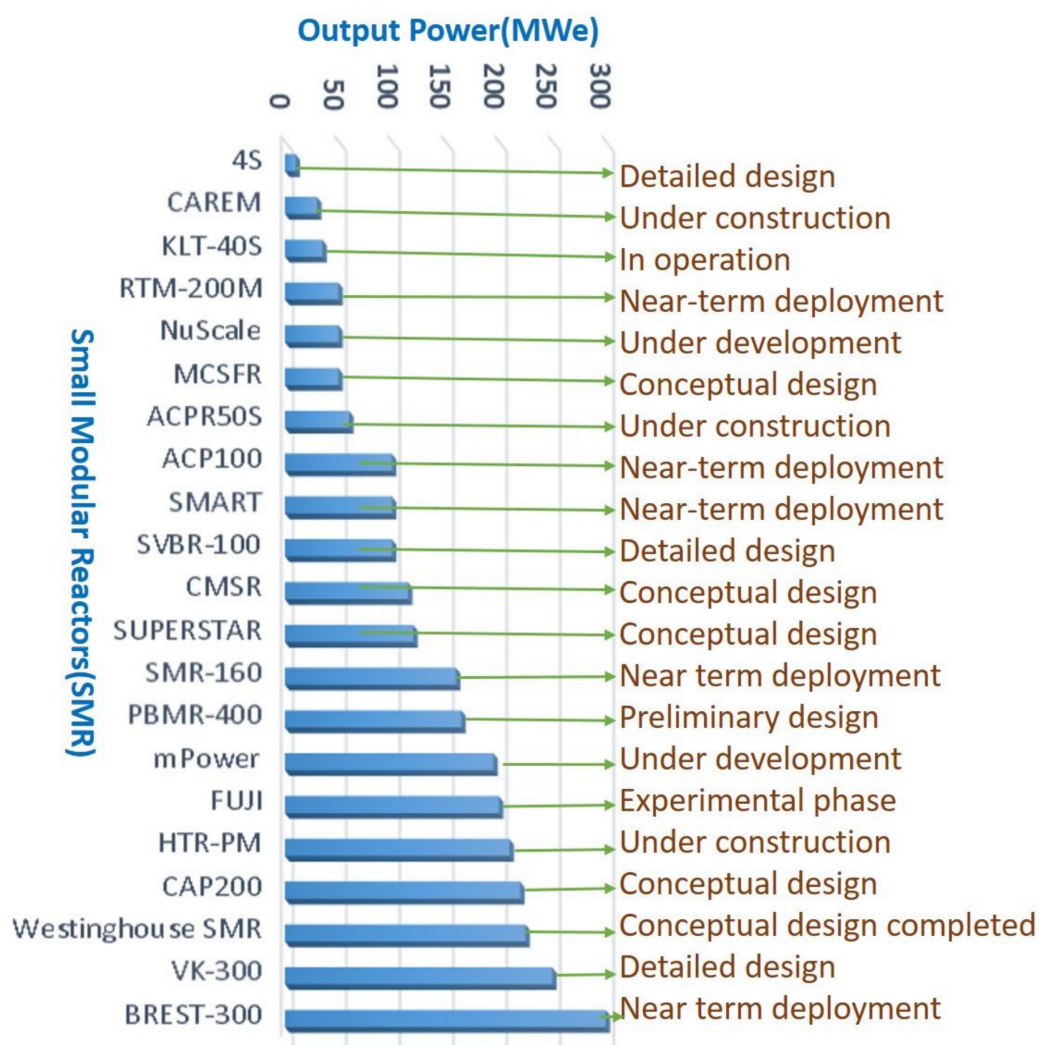

Figure 1. Small modular nuclear reactor with output and status [1].

The new generation of reactor technology, known as Generation IV reactors, which can provide a paradigm shift in the way the world is looking to nuclear technology, is under a consortium named Generation IV International Forum (GIF). There are eight goals formed to support the development of Generation IV reactors to be more safe, reliable, economic, and sustainable to pave the path for nuclear energy generation development and dissemination. A nuclear power plant generates electricity in a similar way to that of thermal power plants. Both plants use steam as the driver fluid introduced into a steam turbine to convert thermal energy into mechanical energy and later to electrical energy in the generator. Thermal power plants use fuel combustion to gain the heat required that converts the water into high enthalpy steam while a nuclear power plant uses nuclear reaction in fission and fusion to utilize the heat for steam generation. Cogeneration of water and power production, which is widely used in dual-purpose steam and combined cycle power plants, appears as an attractive option to also be employed in nuclear plants. Therefore, nuclear desalination is an option that can generate both water and electricity in cogeneration mode, but it may also have some social, economic, environmental, atmospheric, marine, and coastal impact in addition to the site and public acceptance for the deployment of such nuclear power based desalination plants. In this study, various nuclear power plants were discussed, including small modular reactors and those which are developed by some countries for a nuclear desalination option. A comprehensive review was 
presented of the analysis of various studies on nuclear desalination. Comparisons between nuclear and other major renewable energy sources (photovoltaic and wind energy) were performed for cost and other environmental and social aspects. All major social, economic, and environmental aspects of nuclear desalination were discussed. Finally, economic analysis of hypothetical nuclear desalination plants was conducted. The obtained results were verified with others from operating plants so as to confirm our analysis. The prime focus of the study was to highlight and discuss social, economic, and environmental aspects of nuclear desalination plants.

\section{Nuclear Desalination}

Nuclear desalination has already been practiced for a long time in a few countries, such as Japan, India, Kazakhstan, Pakistan, the USA, and Spain with over 150 years of reactor experience. This huge value confirms the techno-economic feasibility of this integrated water production technology but with large-scale nuclear power plants [2]. Previous studies reported zero carbon emissions for nuclear power, making it an environmentally friendly source of energy and, when combined with desalination technologies such as Multiple Effect Distillation (MED), Multi-Stage Flash distillation (MSF), or Reverse Osmosis (RO), lower cost values are obtained for produced electric power and water. Figure 2 gives the current status of all types of nuclear desalination plants, with power output, desalination technology used, water ratio, and country of origin.

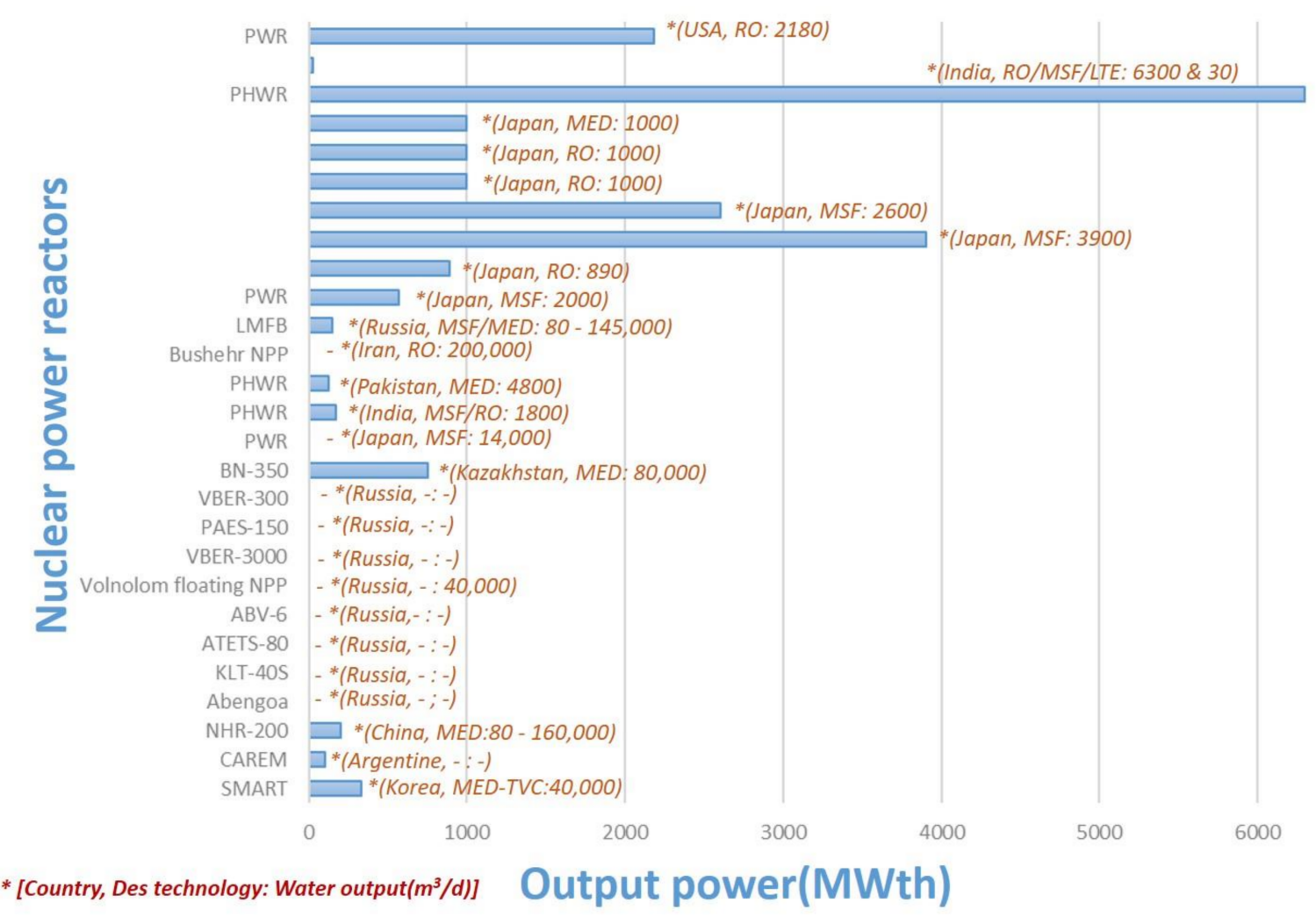

Figure 2. Current status of nuclear desalination units [2].

A number of studies have been performed on nuclear desalination under the guidelines of the International Atomic Energy Agency (IAEA). Many of those studies are based on applying the simulation models with the IAEA nuclear desalination economic program known as the Desalination Economic Evaluation Program (DEEP) [3] and the Desalination Thermodynamic Optimization Program (DETOP) [4]. All these studies reflect the appropriateness and applicability of these nuclear desalination systems. For example, up to $500,000 \mathrm{~m}^{3}$ per day fresh water production from nuclear desalination plants is expected and 
the cost using MED is $1.18-1.45 \$ / \mathrm{m}^{3}$, using MSF $0.60-0.96 \$ / \mathrm{m}^{3}$, and for $\mathrm{RO}$ the range is $0.50-0.94 \$ / \mathrm{m}^{3}$ [2]. Kim and No [5] have drawn their attention to a specific nuclear desalination configuration based on the high-temperature gas-cooled reactor (HTGR) with gas turbomachinery and MED desalination technology. Optimum design of the HTGR-MED coupled systems has been proposed. Besides, a modified version of DEEP tool (k-DEEP) has been developed and used to simulate their new coupled nuclear MED structure. The desalted water cost was found to reach $0.57 \$ / \mathrm{m}^{3}$. The new coupling scheme results in a notable increase of the desalination capacity by more than $250 \%$ and a reduction of water cost by $9 \%$, compared to previous coupling schemes results. Mansouri and Ghoniem [6] recently presented an evaluation of the economics of nuclear and fossil fuel desalination based systems using DEEP. The specifications of an operating MSF plant at Alkhobar, KSA with a capacity of $280,000 \mathrm{~m}^{3}$ / day were used to simulate nine scenarios combining power and desalination plants. MED, MSF, and RO cover the desalination technologies used in the study while power structure include steam Rankine cycle, gas turbine, and combined cycle options. The study considers that these plants are driven either by nuclear or fossil fuel. The results show that the lowest water cost of $0.78 \$ / \mathrm{m}^{3}$ is obtained with the nuclear RO based desalination using steam Rankine cycle followed by the scenario of nuclear MED steam Rankine cycle $\left(1.00 \$ / \mathrm{m}^{3}\right)$. Al-Othman et al. [7] proposed a comprehensive review of nuclear desalination highlighting the main advantages of this coupled technology and the principal challenges facing its development and extensive industrial use. The review compiled a comprehensive summary of produced water cost from nuclear desalination for various nuclear reactor types, various locations, power capacities varying from 115 MWe to $1000 \mathrm{MWe}$, and desalination capacities ranging from $2750 \mathrm{~m}^{3} /$ day to $348,000 \mathrm{~m}^{3} /$ day. The results of this summary show that the cost of water produced by nuclear desalination varies between $0.47 \$ / \mathrm{m}^{3}$ to $2.36 \$ / \mathrm{m}^{3}$. Floating reactor nuclear power plant with a capacity of $100 \mathrm{MWt}$ was used to produce $20,000 \mathrm{~m}^{3}$ / day of fresh water [8]. The DEEP5 program had been employed to simulate the coupled nuclear desalination options considering MED, $\mathrm{MSF}$, and RO processes. The results show that the levelized cost of water from RO is the lowest at $0.80 \$ / \mathrm{m}^{3}$, while the use of MSF is the most expensive at $1.35 \$ / \mathrm{m}^{3}$. A sensitivity analysis on the effect of the discount rate, interest rate, and specific construction cost shows that the above trend is maintained. The dynamic behavior of a nuclear and desalination plant using the integral pressurized water reactor (iPWRs) and MED-TVC process had been investigated by Dong et al. [9]. A plant control strategy based on various control scenarios had been proposed and assessed. Other studies on nuclear desalination are summarized in the next section. Table 1 compiles the results of various references.

Table 1. Most up-to-date literature survey of nuclear desalination.

\begin{tabular}{|c|c|c|}
\hline No. & Literature Survey & Ref. \\
\hline 1. & $\begin{array}{l}\text { A comparison of nuclear with oil and gas in Tunisia concluded that the desalination cost for MED } \\
\text { was half and RO was one third. }\end{array}$ & [10] \\
\hline 2. & A cost comparison of nuclear with fossil fuels in Algeria reported the lowest in case of nuclear. & [11] \\
\hline 3. & $\begin{array}{c}\text { Nuclear desalination is a viable option for potable water in terms of cost comparison with the Egypt } \\
\text { and Tunisia cases. }\end{array}$ & [12] \\
\hline 4. & $\begin{array}{l}\text { A study concluded in KSA desalination plants reveals the lowest cost for nuclear desalination option } \\
\text { in comparison with existing plant. }\end{array}$ & [6] \\
\hline 5. & Advantages and challenges of nuclear desalination. & [7] \\
\hline 6. & Nuclear heating reactor is coupled with MED process to find the cost feasibility. & [13] \\
\hline 7. & Coupling of MED and RO with VC powered by nuclear reactor. & [14] \\
\hline 8. & Nuclear heat for fresh water production with various desalination technologies. & [15] \\
\hline 9. & Karachi nuclear power plant integrated with $\mathrm{RO}$ to find the performance ratio. & [16] \\
\hline 10. & Egyptian nuclear desalination feasibility studies with RO. & [17] \\
\hline 11. & UAE nuclear desalination option studies reveals cost competitiveness. & [18] \\
\hline 12. & Pressurized nuclear reactor feasibility studies for Saudi Arabia. & [19] \\
\hline 13. & Techno-economic analysis of desalination plant in the Middle East region. & [20] \\
\hline 14. & Safety of nuclear desalination plants. & [21] \\
\hline
\end{tabular}


Table 1. Cont

\begin{tabular}{|c|c|c|}
\hline No. & Literature Survey & Ref. \\
\hline 15. & Small modular reactor used for desalination in UAE studies. & [22] \\
\hline 16. & Canadian based nuclear power plant for Saudi Arabia. & [23] \\
\hline 17. & Economy of nuclear desalination plants by hybrid technology. & [24] \\
\hline 18. & Historical analysis of nuclear desalination. & [25] \\
\hline 19. & Eurodesal project for conducting nuclear desalination plant applicability. & [26] \\
\hline
\end{tabular}

Water supply due to population growth and subsidized tariffs in the Middle East region demands alternative resources as it is expected to be among the top 10 water stressed regions by 2040 and is sharply increasing. Nuclear and renewable energy sources are among the most appropriate to cope with this issue and a few countries in the Middle East region have already started their ambitious plans. Solar and nuclear driven desalination plans are expected to be implemented soon. Therefore, it is important to conduct comparative studies on the cost of these two energy resources as well. Figure 3 shows a general picture of the cost of water production for nuclear and solar desalination technologies.

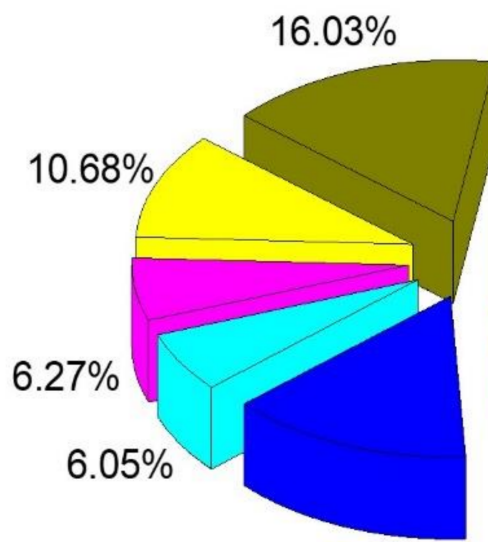

$14.25 \%$
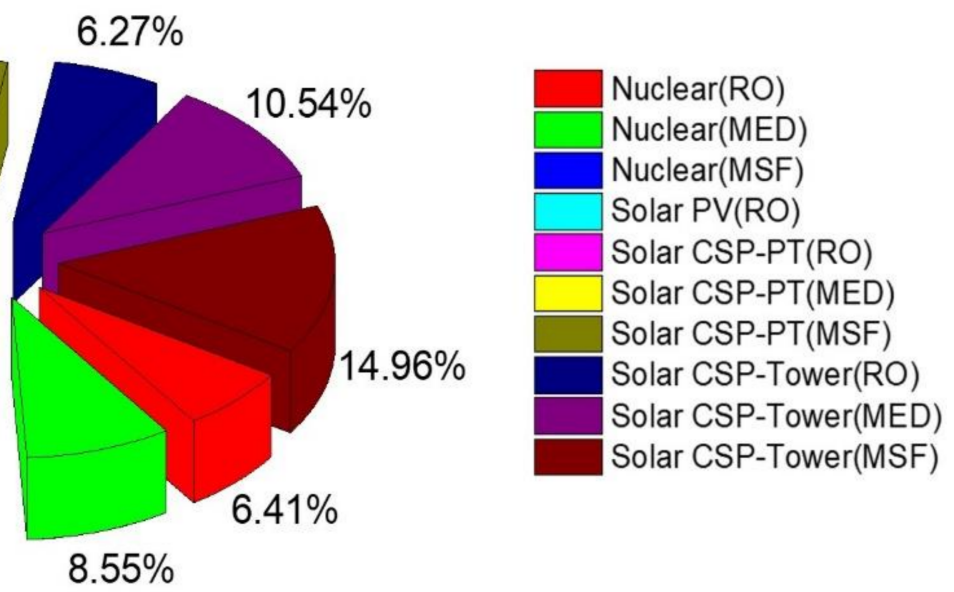

Figure 3. Water desalination cost of nuclear and solar energy coupled units [27].

It is important to understand that nuclear footprints are smaller than those of other renewable energy resources, such as wind or solar energy. A general comparison of land used by nuclear, wind, and solar is presented in Table 2.

Table 2. Installed capacity against area occupied by nuclear, wind, and solar energy [28].

\begin{tabular}{ccccc}
\hline $\begin{array}{c}\text { Energy } \\
\text { Source }\end{array}$ & $\begin{array}{c}\text { Installed } \\
\text { Capacity (MWe) }\end{array}$ & $\begin{array}{c}\text { Capacity } \\
\text { Factor (\%) }\end{array}$ & $\begin{array}{c}\text { Per Year Generation } \\
\mathbf{( M W h / Y e a r )}\end{array}$ & $\begin{array}{c}\text { Area Occupied } \\
\left.\mathbf{( k m}^{\mathbf{2}} \mathbf{(}\right)\end{array}$ \\
\hline Nuclear & 1000 & 90 & $7,884,000$ & 3.367 \\
\hline PV (high) & 3214 & 28 & Same & 52.031 \\
\hline PV (low) & 5294 & 17 & - & 85.698 \\
\hline Wind (high) & 1915 & 47 & - & 612.766 \\
\hline Wind (low) & 2813 & 32 & - & 900 \\
\hline
\end{tabular}

The current status of water desalination plants operating in some countries is explained below.

- Saudi Arabia is constructing a nuclear power reactor named System Integrated Modular Advanced Reactor (SMART) from South Korea which is a dual-purpose plant producing $100 \mathrm{MWe}$ and 40,000 $\mathrm{m}^{3}$ / day of potable water [2]. In Saudi Arabia, the water production from seawater is managed by the Saline Water Conversion Co- 
operation (SWCC) which produced about 7.3 $\mathrm{Mm}^{3}$ / day by 2020. Integration of the power with desalination plants is based on the utilization of the rejected heat for water production, thus reducing the energy necessities to half.

- Pakistan deployed $30 \mathrm{RO}$ based desalination plants in Sindh province and one plant with $2000 \mathrm{~m}^{3}$ /day capacity in Gwadar city. Also, a China-Pakistan joint venture produced $23,000 \mathrm{~m}^{3}$ / day and $189,000 \mathrm{~m}^{3} /$ day, respectively, of seawater desalination [29].

- Kuwait is looking for $1000 \mathrm{MWe}$ coupled desalination plant to produce $140,000 \mathrm{~m}^{3} /$ day in addition to the Az-Zour gas-fired plant of 1500 MWe operating with $486,000 \mathrm{~m}^{3} /$ day of water capacity [30].

- Two units of nuclear desalination at El-Badaa region in Egypt are planned to have the greatest desalination capacity of the country. Already existing units produce about $24,000 \mathrm{~m}^{3}$ /day at Masra region, 150,000 $\mathrm{m}^{3}$ /day at El-Alamein region, and many others are under construction in various regions [31].

- India utilized both RO and MSF technology for desalination and assisting plant to produce $45,000 \mathrm{~m}^{3}$ /day of water, $100,000 \mathrm{~m}^{3} /$ day in Chennai and in Nemmeli and some are other parts of the country [32].

\section{Socio-Economic Analysis}

The higher development potential of nuclear desalination plants is due to the availability of energy and water but this may change due to many social and economic factors, such as people, capital, and resources. Nuclear desalination not only depends on technical and regularity issues like other development projects, but concerns of local citizens and nongovernmental organizations can hinder the licensing process. Therefore, it is necessary to identify public opinion and acceptance. This includes the acceptance of nuclear power and desalination plants, in conjunction with other safety issues, public health, environmental impacts, water and energy supply, and financial constraints.

As per the economy of scale, the typical commercial nuclear power plant is in the range of 1000-1600 MWe [33] for it to be able to produce, ideally, $100,000 \mathrm{~m}^{3} / \mathrm{d}$ capacity at a fraction of the power used [34]. It shows the prime concerns are energy demand and supply, despite water demand. In addition, there should be a clear demand for the rest of the power produced, which is connected to the grid for distribution. Compared to power, the availability of water is geographically limited, with the result its availability may not be as dispersed over large areas. Other prominent issues include tourist and recreational places, fisheries, and navigational and other residential and commercial areas. For the new nuclear desalination plants, in addition to safety concerns, the huge capital cost, higher uncertainty with respect to finances, and schedule time (longer construction time), are enough parameters to spark public opposition. In this case, only government involvement can convince those investors reluctant to support the project.

Production of fresh water has a positive impact on society as it can fill the gap between supply and demand in addition to the already available water storage. But this availability varies when it is largely dependent on development plans and water management which controls the growth in compliance with other related factors. For example, a desalination plant in Spain [35] produces about 3000 litres/day per person despite the fact that it is one of the driest region in Europe and it is then used to export to the fertile region for massive and good quality food production [36]. The case of a nuclear desalination plant built in Aktau (Kazakhstan) to support the development of the city and for industrial applications is worth analyzing. In a few years (1970-1999), the desert-like city of Aktau was completely transformed into a developed coastal city, further stimulating the economic and population growth which increased from a few hundred to 155,000 people. In Saudi Arabia, water availability truly impacts the socio-economic situation. The country offers subsidies despite the fact that it required two to three times more water for agriculture than a temperate country [37]. This led to the decision to end heat production in 2016 followed by the drastic changes in a society which suddenly had water availability. This is the reason that Saudi Arabia is looking for alternate options of producing fresh water, such 
as from nuclear and renewable energy sources. Table 3 gives a clear picture of the range of the cost of water from various conventional desalination technologies. It can be observed that RO technology offers cost-effective values but MSF and MED can also take advantage of economy of scale because their specific cost decreases with increased plant capacity. This implies that a large desalination plant using MED can achieve specific investment costs comparable to an RO plant.

Table 3. Investment and water cost of major desalination technologies [38].

\begin{tabular}{ccc}
\hline Desalination Technology & Investment Cost $\left(\$ / \mathbf{m}^{\mathbf{3}} /\right.$ day) & Water Output Cost $\mathbf{( \$ / \mathbf { m } ^ { 3 } )}$ \\
\hline MSF & $1200-1500$ & $1.10-1.25$ \\
MED & $900-1000$ & $0.75-0.85$ \\
RO & $700-900$ & $0.68-0.82$ \\
\hline
\end{tabular}

According to IAEA, the development of nuclear desalination is cost-effective and technically feasible in a variety of reactors and related site conditions. There is significant cost reduction if a nuclear desalination plant is located closer to an already existing water distribution supply network. For generation (Gen) III, III+, and IV nuclear reactors, the amount of electricity produced can be accommodated easily and quickly due to innovative and safer design, thus increasing the adoptability of nuclear desalination with low cost. Because large nuclear power plants (mostly Gen I and II) are cost intensive as they need at least five years to build while small modular reactors (mostly Gen III, III+, and IV) take three years, this will decrease the cost of coupling with any desalination plant. But the question about public perception relies on the safety of the plant, the huge capital cost, longer construction time, and the higher degree of uncertainty due to finances and other schedules which may influence investors' interest in supporting the project [38]. The best example was in the United States where 41 plants were cancelled in 1973 due to rising capital cost, fuel cost, economic issues, as well as environmental issues [39]. However, the existence of established nuclear power plants may help to reduce or avoid opposition to nuclear power technology, including siting, cost, and construction (no such experience reported). Many countries are interested in the deployment of nuclear power plants which indicates that they may move on to the nuclear desalination option in the future. For a more economic nuclear desalination model to be designed, other factors such as tax revenues, interest rates, land occupation, jobs, community development, public acceptance, and social and economic growth should be considered. Since any nuclear power plant requires public acceptance, there exists a communication and information program rating public concerns and, as much as involves the public, its increasing confidence in the deployment of nuclear desalination. Countries like the USA, France, and South Korea have introduced a polling system to gauge public acceptance of nuclear power plant development.

\section{Environmental Impact}

There is no dismissing the environmental impact of nuclear desalination but some studies have reported various impacts due to many factors, such as technology, operation, hydrology, geographical, desalination capacity, and meteorological conditions. Therefore, it is important to consider environmental assessments to investigate possible impacts and propose optimal solutions. Table 4 presents some of the major impacts associated with nuclear desalination.

Nuclear desalination options present an environmentally friendly alternative in terms of water and energy storage which can be considered as a trade-off between intake and discharge. It can be said that if existing nuclear power plants are not equipped with retrofitted and closed cooling systems and have no suitable technology to reduce the impact, nuclear desalination can be considered. Recommended safety design can resolve the problem of adverse marine impacts for the specific location of the plant. Therefore, both coastal and atmospheric impacts can have negligible effect on nuclear desalination. Regarding environmental impact, it is important to consider coastal and marine issues 
leading to the depletion of the coastal ecosystem, contributing to the cumulative adverse impacts of nuclear desalination. This is due to liquid multi component waste discharge contributing to the disturbance of the biological, coastal, and marine ecosystems. The quality of the desalination might be degraded due to reduced efficiency and reduced quality of the desalination process. Seawater impact and effluent discharge are well known factors to be considered by the power generating industry, including co-location of the desalination plant with the power plant that involves addressing additional issues of high salinity and the chemical composition of the brine discharge.

Table 4. Summary of the main environmental impacts of nuclear desalination.

\begin{tabular}{|c|c|}
\hline Impact & Reason \\
\hline Coastal & Noise, construction, visual impacts, and land requirements. \\
\hline Marine & Intake of seawater, brine discharge, operations, characteristics, etc. \\
\hline Siting and co-location & Water transport, environmental concerns, and overall impact. \\
\hline Sustainability & $\begin{array}{c}\text { Energy and water availability, relocation of the population, economic } \\
\text { competitiveness, sustainability, etc. }\end{array}$ \\
\hline Public health & Quality, reliability, radiation, safety, and water produced. \\
\hline Public perception & Plant safety and fresh water production without radiations. \\
\hline
\end{tabular}

Compared to fossil fuel and renewable energy, nuclear desalination offers good opportunity of causing low levels of atmospheric impact. As such, it can generate large heat losses which can be used for seawater desalination with no atmospheric impacts. It is observed that the area occupied by nuclear desalination should be the best available option for potable water and energy.

In nuclear power plants, there is no fuel to be wasted if it can be reprocessed and recycled appropriately prior to final disposal. It is important to guarantee the integrity of the marine environment, which should not be affected by the seawater used by the condenser cooling system, as well as other factors. These are the factors which contribute to the environmental impact of nuclear power. Brine, liquid multicomponent, waste discharge, and high salinity contribute to the depletion of the coastal ecosystem. Therefore, needless to say, the nuclear desalination option is especially to be considered within the standards and policies of nuclear and desalination technology.

The combination of nuclear energy with any system which requires thermal energy as a driving force is developed and becomes widely used throughout the world because of its high production of heat. It could be combined with industrial applications, agriculture, medicine, and water. Water and energy are two essential factors in our daily lives. Water sources are available naturally in rivers, lakes, ground water, and seas. In order to use these sources, special treatment must be applied, which differs depending on each application. Many systems have been developed in past years which treat water, such as multi-stage evaporation which consumes a lot of energy in order to produce treated water. Recently, advanced systems which used special membranes and thermal processes, such as multieffect (ME), multi-stage (MS), reverse osmosis (RO), nano-filtration, and ultra-filtration systems, were developed in order to treat water with much less energy consumption and are currently widely used. Figure 4 illustrates some combinations of nuclear power plant, MED, MSF, and RO desalination systems. For such systems which use seawater as a feed and operate by using a nuclear reactor to supply steam at specific temperature, many parameters must be evaluated depending on water salinity, such as the size and type of the reactor, and the implementation of the nuclear cycle, starting from the availability of the nuclear substance, which is mainly uranium, that is widely available, and ending with the disposal of the radioactive waste. Mostly, nuclear water-cooled reactors are used in water desalination due to their advanced state of development and deployment. It is important to note that newly built nuclear power plants need to be adequately environmentally assessed in order to be licenced and co-located plants are easier for this. Many older nuclear desalination plants had not obtained such environmental licences. 


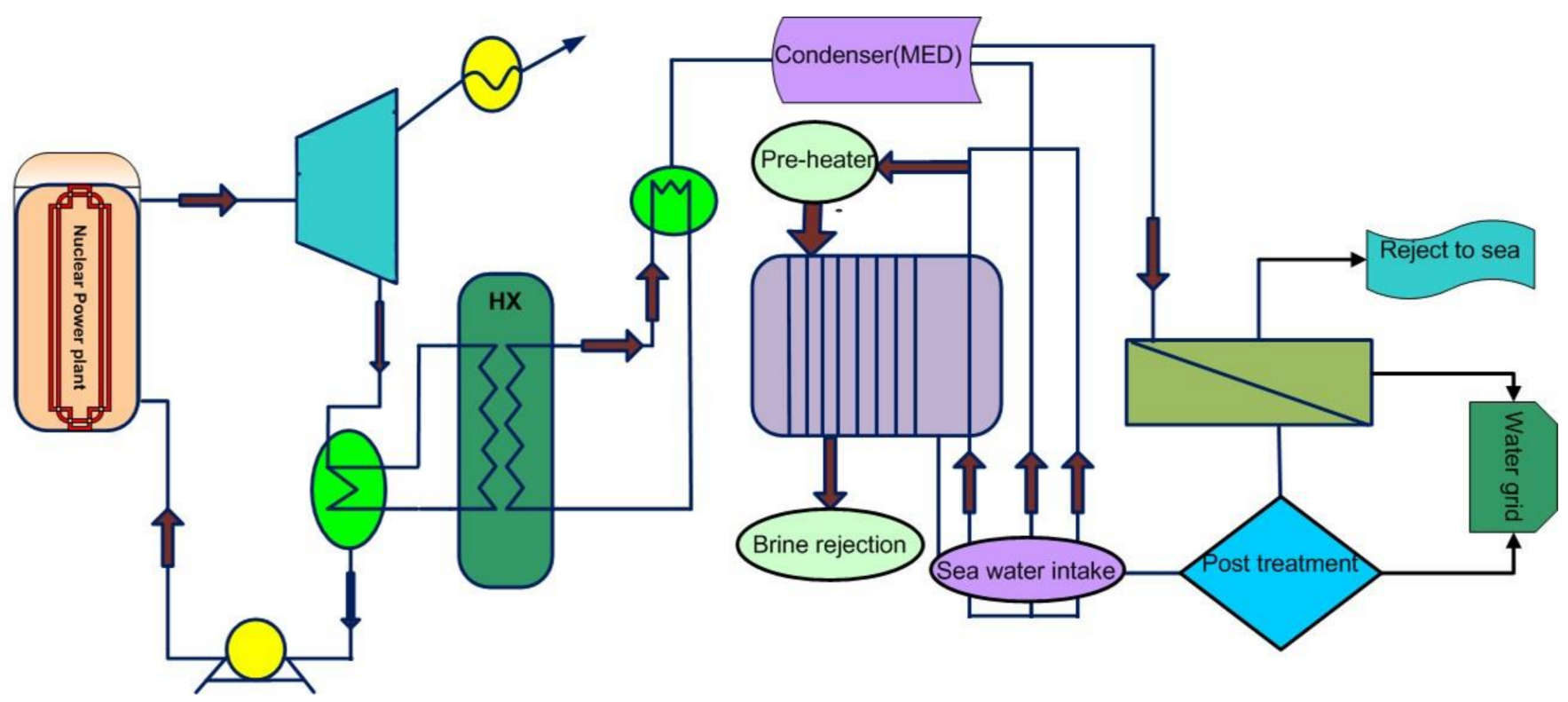

Figure 4. Coupling of a nuclear power plant with both RO and MED desalination systems.

Based on the above discussion, it has been observed that specific operational practices of nuclear desalination suggest the following features of social, economic, and environmental aspects:

1. Environmental impacts related to coastal locations for nuclear desalination are lower than other co-located plants, irrespective of the energy source;

2. There is no apparent evidence of enhancing the adverse effects of nuclear desalination on marine habitats, similar to other co-located plants;

3. The discharge of brine into the sea may harm marine life systems if it is not diluted with coolant discharge from the reactor;

4. The radiation safety of a nuclear desalination plant as well as other safety features are of a highly satisfactory level;

5. Data on public acceptance of nuclear desalination is quite limited but it indicates positive views (higher than the required limit);

6. Compared to other desalination plants, nuclear desalination is able to mitigate the negative environmental impact to a large extent, and is even cleaner than renewable energies;

7. Both social and economic impacts of nuclear desalination can be of a higher rate compared to other desalination plants, mainly due to cheap electricity and water production (depending upon how it has been used); and

8. Advanced nuclear reactors may overcome existing challenges, such as infrastructure development, financial and capital cost, public perception, and human resources.

\section{Preliminary Economic Analysis of Nuclear Desalination}

For the preliminary assessment, we developed some configurations for various options of desalination technology with nuclear power reactors. The observation was made on both heat-only cases as well as heat and electricity cases. The possible configurations for both cases are as follows:

1. Coupling of nuclear reactor with MED technology;

2. Coupling of nuclear reactor with MSF technology;

3. Coupling of nuclear reactor with RO technology;

4. Coupling of nuclear reactor with RO and MED technology; and

5. Coupling of nuclear reactor with RO and MSF technology. 
The above configurations are used to calculate the capital and operating and expenditures (CAPEX and OPEX) of the desalination system to find the total water cost. The flow diagram of the process is presented in Figure 5.

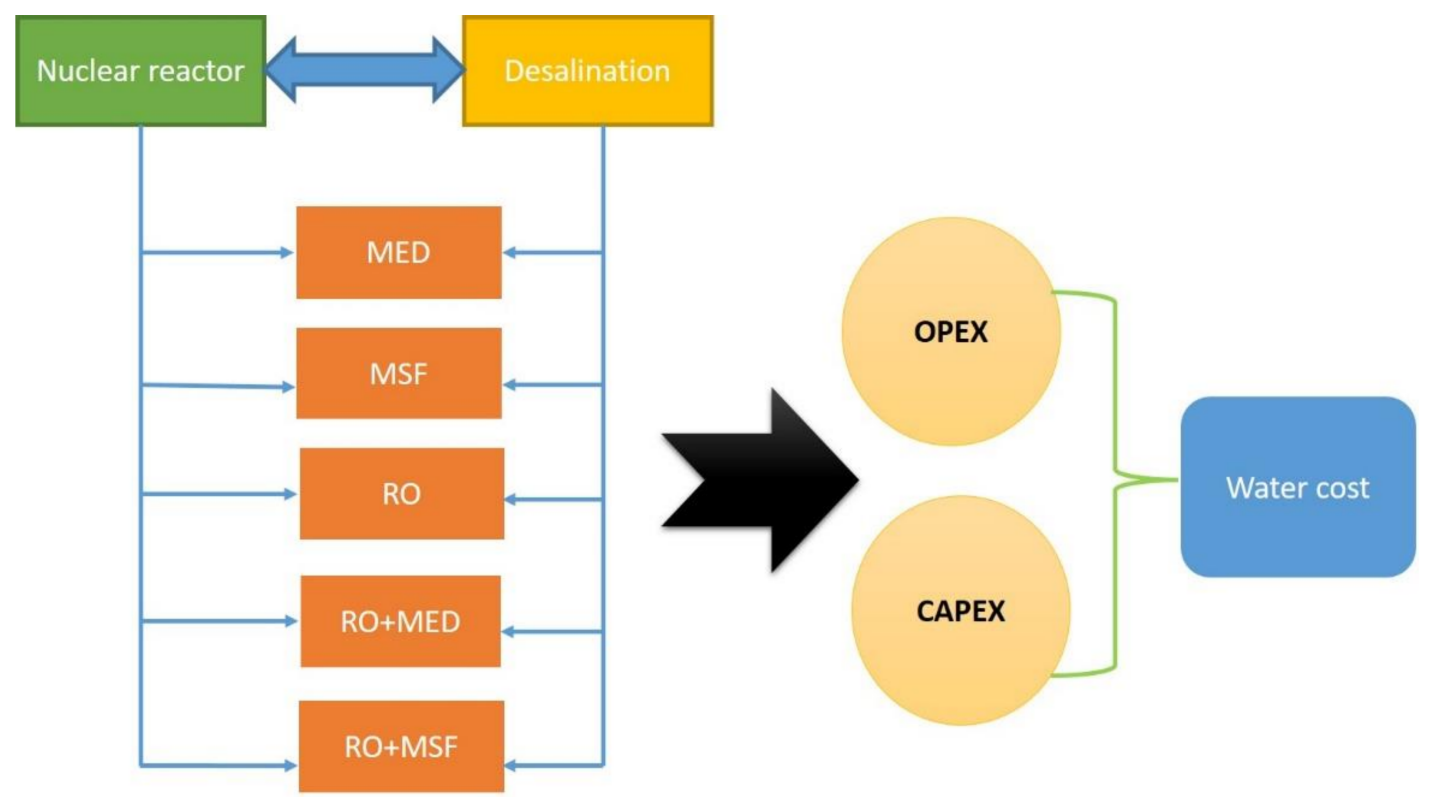

Figure 5. Flow diagram of the coupled nuclear desalination systems with various configurations.

The above configurations were designed to conduct preliminary assessment of nuclear desalination options. For this purpose, Desalination Economic Evaluation Program (DEEP) was used, which is a cost-estimation tool designed by the International Atomic Energy Agency (IAEA). The program can be used to evaluate desalination strategies by estimating the technical performance and costs of various energy sources driving desalination technology configurations. The modeling of the desalination system includes multi-stage flashing (MSF), multi-effect distillation (MED), reverse osmosis (RO), and hybrid options (RO-MSF, RO-MED) while energy source options include nuclear, fossil, renewables, and grid electricity (stand-alone RO) [40]. The tool allows decision-makers and designers to compare performance and cost estimates of the various coupled desalination and power configurations. DEEP can model and calculates both co-generation of water and electricity as well as water-only plants. It also estimates a comparison of a number of design alternatives, which helps in the identification of the lowest cost options for water and power production for any specific location. Generally, the desired configurations, water capacities, and power are the main parameters, including various other basic parameters and cost data [3]. The schematic diagram and working mechanism of DEEP is illustrated in Figure 6.

In DEEP, the input data includes calculation of energy sources and desalination plant performance, costs, and economic evaluation. Generally, the required input data includes water capacity, distillation capacity, and membrane type. These parameters determine the required power plant capacity, the lost electric power, the construction cost, and operation and maintenance cost. It also includes the choice of water plant type. The distillation plant determines the gain output ratio (GOR) which is defined as how much water is produced with a certain amount of steam. This also determines the construction cost and energy cost of the water plant. However, the empirical relations for the construction and energy consumption costs are different but are included in the DEEP program equations.

Technical input parameters include the temperature of cooling water (average) and seawater total dissolved solids (TDS). It is estimated that if the average cooling water temperature changes from the reference condensing temperature of the power plant then the net electric capacity is recalculated again. In addition, the higher the TDS values the 
higher will be the energy consumption in the RO plant, thus the higher the TDS in the product water. Other technical parameters include generator efficiency, factor for auxiliary load, turbine mechanical efficiency, and electric motor efficiency.

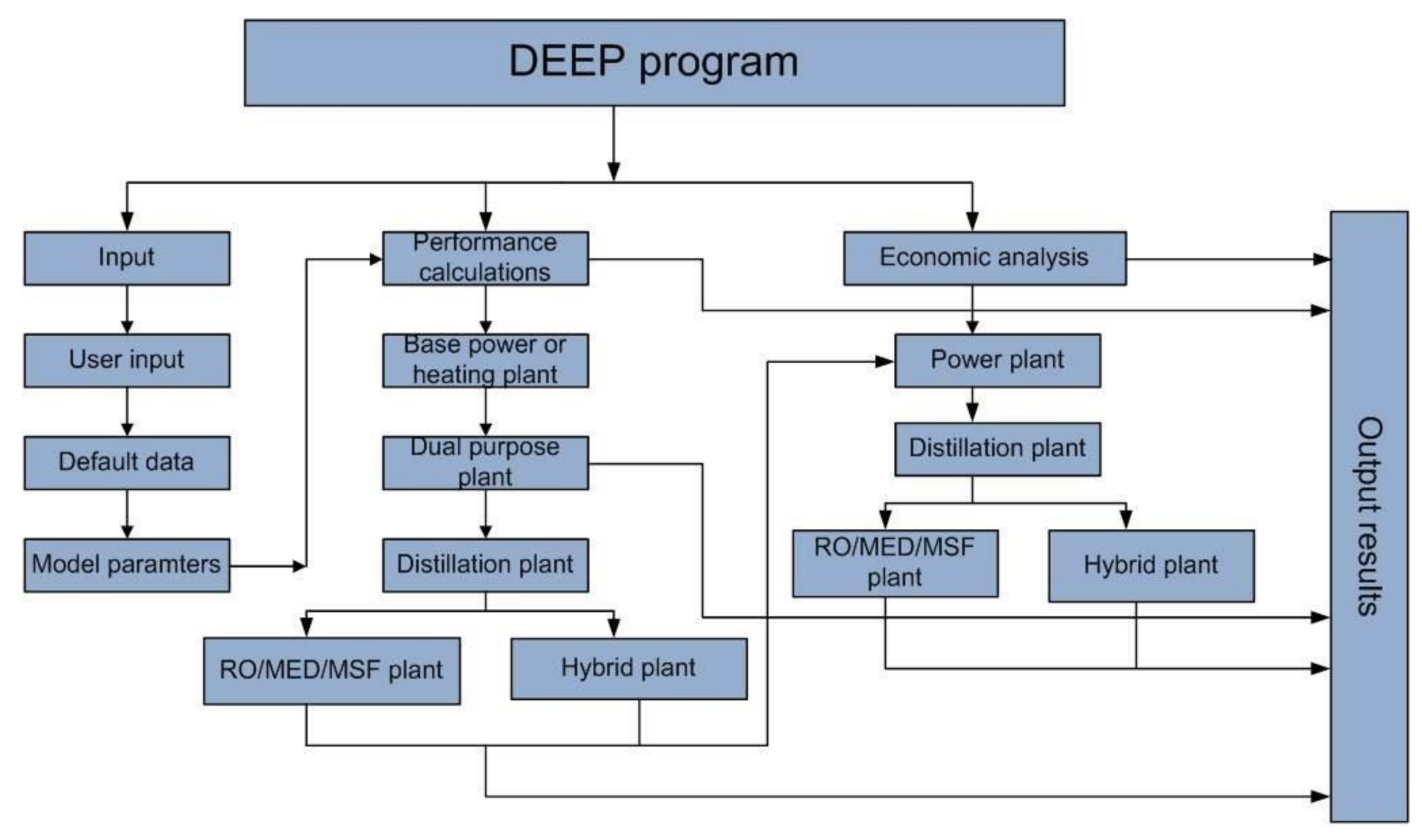

Figure 6. Working mechanism of DEEP.

Energy plant performance input parameters include base power plant and the number of units on site, reference net thermal efficiency, and intermediate loop for heat transfer to the water plant, while the reference base power plant unit electric output in many cases can be determined by the electricity supply plan. Other relevant parameters include planned/unplanned outage rate, site-specific air inlet temperature, and reference condensing temperature of the base power plant.

In this study, a nuclear power plant was modeled with various desalination units in DEEP software by using the input parameters listed in Table 5 while the output parameters include the total capital and operating cost (CAPEX and OPEX) of water as given in Table 6. All other default parameters (presented in Tables 7 and 8) were used according to our specified input data (Table 5). All the technical models used in the program are based on simple thermodynamic cycle calculations and empirical expressions for the purpose to estimate the economic model input. Both technical and economic parameters provide the basis of unique configuration, for example, steam cycle, gas cycle, combine cycle, and heat-only cycle.

Table 5. Input parameters for DEEP.

\begin{tabular}{cc}
\hline Parameters & Values \\
\hline Desalination plant capacity & $100,000 \mathrm{~m}^{3} /$ day \\
Total dissolved salts & $42,000 \mathrm{ppm}$ \\
Feed water inlet temperature & $30{ }^{\circ} \mathrm{C}$ \\
Discount rate & $5 \%$ \\
Interest rate & $5 \%$ \\
Fuel escalation rate & $3 \%$ \\
Maximum brine temperature & $70{ }^{\circ} \mathrm{C}$ \\
Thermal efficiency & $33 \%$ \\
Lifetime of plant & 30 years \\
Operational availability & $90 \%$ \\
\hline
\end{tabular}


Table 6. Capital and operating cost of water with and without electricity.

\begin{tabular}{|c|c|c|c|c|c|c|c|c|}
\hline \multirow{2}{*}{ Fuel } & \multirow{2}{*}{ Cycle } & \multirow{2}{*}{ Distillation } & \multicolumn{2}{|c|}{ CAPEX $\left(\$ / \mathrm{m}^{3}\right)$} & \multicolumn{2}{|c|}{$\operatorname{OPEX}\left(\$ / \mathrm{m}^{3}\right)$} & \multicolumn{2}{|c|}{ Water Cost $\left(\$ / \mathrm{m}^{3}\right)$} \\
\hline & & & This Work & Refs $[6,39]$ & This Work & Refs $[6,39]$ & This Work & Refs $[6,39]$ \\
\hline \multirow{10}{*}{ Nuclear } & \multirow{5}{*}{ Steam cycle } & MED & 0.44 & $0.41[6]$ & 0.54 & $0.59[6]$ & 0.981 & $1.0[6]$ \\
\hline & & MSF & 0.46 & $0.46[6]$ & 1.04 & $0.36[6]$ & 1.504 & $0.82[6]$ \\
\hline & & $\mathrm{RO}$ & 0.34 & $0.34[6]$ & 0.47 & $0.44[6]$ & 0.810 & $0.78[6]$ \\
\hline & & $\mathrm{RO}+\mathrm{MED}$ & 0.46 & - & 0.57 & - & 1.035 & - \\
\hline & & $\mathrm{RO}+\mathrm{MSF}$ & 0.46 & - & 1.04 & - & 1.504 & - \\
\hline & \multirow{5}{*}{ Heat only } & MED & 0.52 & $0.51[39]$ & 1.283 & 1.3 [39] & 1.803 & $1.81[39]$ \\
\hline & & MSF & 0.65 & 0.59 [39] & 1.527 & $1.77[39]$ & 2.177 & $2.36[39]$ \\
\hline & & $\mathrm{RO}$ & 0.41 & 0.39 [39] & 0.487 & 1.11 [39] & 0.897 & 1.5 [39] \\
\hline & & $\mathrm{RO}+\mathrm{MED}$ & 0.50 & 0.48 [39] & 1.357 & $1.4[39]$ & 1.857 & 1.88 [39] \\
\hline & & $\mathrm{RO}+\mathrm{MSF}$ & 0.50 & 0.48 [39] & 1.352 & - & 1.852 & - \\
\hline
\end{tabular}

Table 7. Parameters of Power plant cycle [3].

\begin{tabular}{|c|c|c|c|c|}
\hline Operational Data & Steam Cycle & Gas Cycle & $\begin{array}{l}\text { Combine } \\
\text { Cycle }\end{array}$ & $\begin{array}{c}\text { Heat-Only } \\
\text { Cycle }\end{array}$ \\
\hline Lifetime of energy plant (months) & 60 & 40 & 40 & 60 \\
\hline Construction lead time (years) & 60 & 24 & 24 & 40 \\
\hline Technology efficiency (\%) & 32 & 42 & 55 & 90 \\
\hline Carbon emission $(\mathrm{kg} / \mathrm{kWh})$ & 0.029 & 0.029 & 0.029 & 0.01 \\
\hline Specific construction cost $(\$ / \mathrm{kWe})$ & 4000 & 3500 & 4000 & 1300 \\
\hline Specific fuel cost $(\$ / M W h)$ & 5.9 & 6.0 & 4.5 & 3.3 \\
\hline Primary fuel price (\$/tons) & 1.9 & 2.5 & 2.5 & 3 \\
\hline Specific O\&M cost (\$/MWh) & 8.8 & 12 & 12 & 2 \\
\hline Additional site-related tax (\%) & 10 & 10 & 10 & 10 \\
\hline Energy plant contingency (\%) & 0 & 0 & 0 & 0 \\
\hline Plant decommissioning (\%) & 15 & 15 & 15 & 15 \\
\hline
\end{tabular}

Table 8. Desalination model parameters [3].

\begin{tabular}{cccc}
\hline Operation \& Performance Data & MED & MSF & RO \\
\hline Lifetime of water plant (years) & 20 & 20 & 20 \\
Lifetime of backup heat (years) & 20 & 20 & - \\
Water plant lead time (months) & 12 & 12 & 12 \\
Water plant planned outage rate $(\%)$ & 3 & 3 & 3.2 \\
Water plant unplanned outage rate $(\%)$ & 6.5 & 6.5 & 6.0 \\
Base unit cost $\left(\$ / \mathrm{m}^{3} / \mathrm{d}\right)$ & 900 & 1000 & 900 \\
Backup heat source $(\$ / \mathrm{MWt})$ & 55,000 & 55,000 & - \\
Specific O\&M spare part cost $\left(\$ / \mathrm{m}^{3}\right)$ & 0.03 & 0.03 & 0.04 \\
Tube replacement cost $\left(\$ / \mathrm{m}^{3}\right)$ & 0.01 & - & - \\
O\&M chemical cost for pre-treatment $\left(\$ / \mathrm{m}^{3}\right)$ & 0.03 & 0.03 & 0.03 \\
O\&M chemical cost for post-treatment $\left(\$ / \mathrm{m}^{3}\right)$ & 0.02 & 0.02 & 0.01 \\
O\&M membrane replacement cost $\left(\$ / \mathrm{m}^{3}\right)$ & - & - & 0.07 \\
In/outfall cost factor $(\%)$ & 7 & 10 & 7 \\
Water plant cost contingency factor $(\%)$ & 10 & 10 & 10 \\
Water plant O\&M insurance cost $(\%)$ & 0.5 & 0.5 & 0.5 \\
\hline
\end{tabular}

A block diagram of coupled nuclear desalination system illustrated in Figure 7.

It is well understood that the cost of fresh water is directly proportional to water quality. Therefore, if product quality is higher then the cost of water will also increase and vice versa. Based on the modeled configurations in DEEP, it has been observed that membrane processes, such as RO, show lower cost as compared to thermal process (MED or MSF) but produced water quality of thermal processes is always higher than membrane process. Table 8 illustrates that the lowest cost is achieved when the nuclear power plant is coupled with RO, MED, MSF, RO + MSF, and RO + MED for both cases (with heat only 
and with heat + electricity). The research was extended to compare the results with other coupled nuclear desalination plants with similar configurations. One case study [6] was the nuclear fuel-based desalination plants with MED, MSF, and RO with steam cycle by using DEEP software, it was observed that our analysis is very close to the selected case study which compared the fossil and nuclear desalination option. The study suggests that a much lower cost was observed in the case of a steam cycle with $\mathrm{RO}$ and considered to be the cheapest among other steam cycle scenarios which are the same as observed in our analysis.

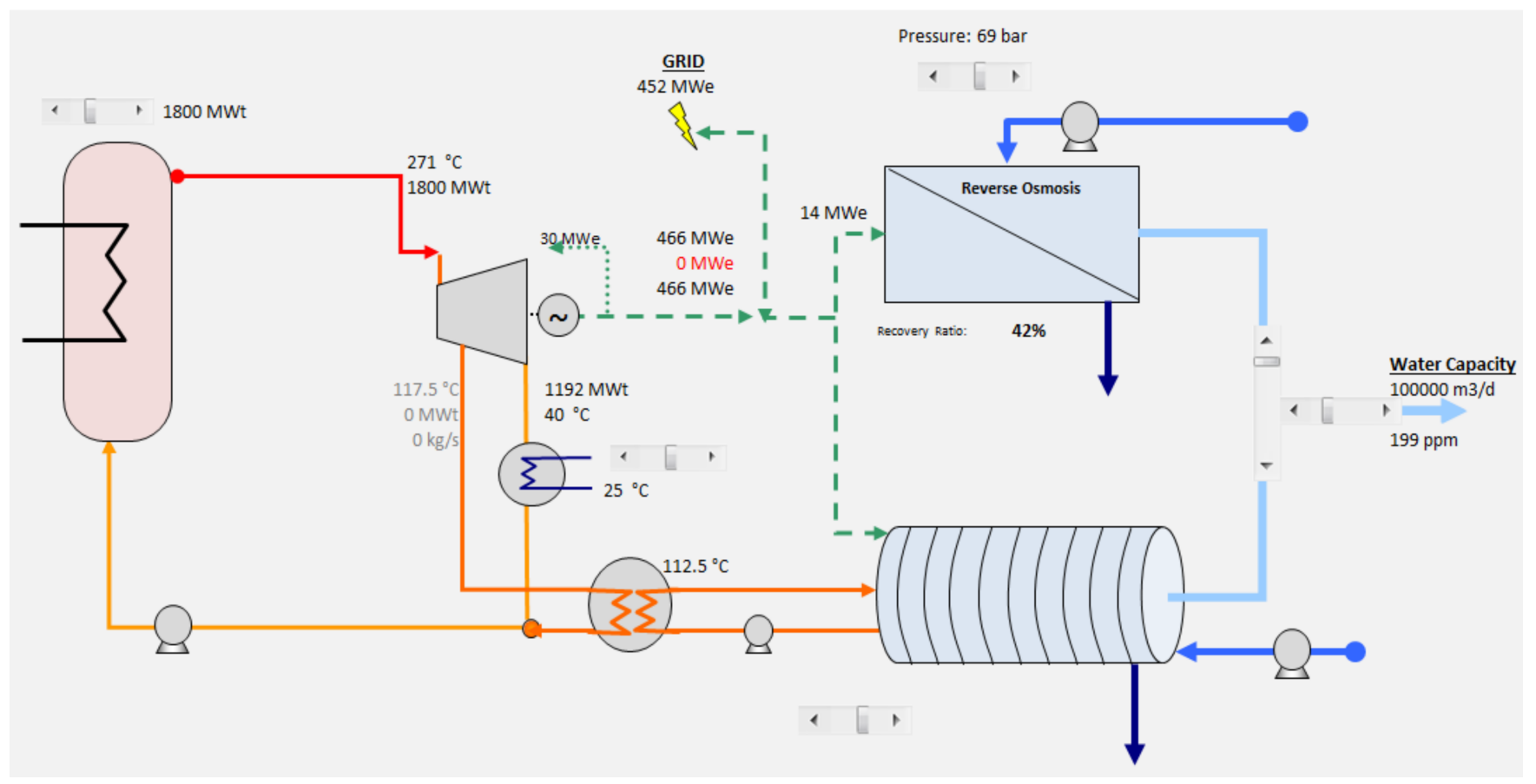

Figure 7. Sketch of coupled nuclear desalination system by using DEEP.

For heat-only case, we have used our past study on Central Argentina de Elementos Modulares (CAREM) Argentine nuclear power plant with similar desalination configurations [39] and it was found very close to the current work. It can be seen that the lowest values were obtained in the case of $\mathrm{RO}$ and the maximum values from MSF in both studies. Similarly, other coupled configurations have the same trends, thus validating our analysis. These verification studies were performed to confirm our simulation results.

The coupling with MED appears to be the next economical case while MSF coupled nuclear power plant proved to be the most expensive unit. In the case of integrating two desalination technologies, such as MED + RO or MSF $+\mathrm{RO}$, it has been observed that the $\mathrm{RO}+\mathrm{MED}$ gives the most economical values as compared to RO + MSF. These results show that the ideal solution of nuclear desalination is to have nuclear with either membrane or combined with thermal desalination (MED only). The results give the preliminary assessment of the nuclear desalination option for any country which is interested in adopting this technology. For those countries which offer subsidized rates for fresh water production, this tends to increase the cost of the water. Adoption of nuclear desalination technology is a difficult decision because there are two outputs (in combined or steam-cycle cases), i.e., water and electricity, and each of these two needs to be treated separately. This means that the profit of each product is independent of the other. Sometimes, electricity production and the selling rate shows profit while in the same case desalination costs need to be comprised and sold at lower cost. In this case, the government supports the situation and tries to finalize the cost equivalent to a stand-alone nuclear power plant. 
For validation and verification analysis, the same methodology was used to compare with other power cycle options. In this case, the results of the IAEA coordinated research project [40] were used in which three reactors-a gas turbine-modular helium cooled reactor (GT-MHR), a pebble bed modular reactor (PBMR), and a turbine combined cycle plant (CC-600) - were taken. Various economic parameters of these reactors were used as input to the DEEP so as to evaluate the desalination costs. The main output is presented in Table 9. It can be observed that the GT-MHR shows the lowest cost followed by the PBMR and the CC-600, which is exactly the same as in our analysis. The obtained results verify the conclusion of our studies.

Table 9. Comparisons of nuclear with other power cycles.

\begin{tabular}{cccccccc}
\hline Parameters & Units & \multicolumn{2}{c}{ GT-MHR } & \multicolumn{2}{c}{ PBMR } & \multicolumn{2}{c}{ CC-600 } \\
\hline & & $\begin{array}{c}\text { This } \\
\text { Work }\end{array}$ & Ref [40] & $\begin{array}{c}\text { This } \\
\text { Work }\end{array}$ & Ref [40] & $\begin{array}{c}\text { This } \\
\text { Work }\end{array}$ & Ref [40] \\
\hline $\begin{array}{c}\text { Thermal } \\
\text { power }\end{array}$ & MWth & 593 & 592.6 & 136 & 114.9 & 1069 & 1069 \\
\hline Electric power & MWe & 286 & 286.6 & 315 & 265.9 & 545 & 545.2 \\
\hline Efficiency & $\%$ & 48 & 48.3 & 50 & 48.3 & 50 & 51 \\
\hline Availability & $\%$ & 82 & 91.2 & 81 & 91.2 & 81 & 90.3 \\
\hline $\begin{array}{c}\text { Construction } \\
\text { lead time }\end{array}$ & Years & 4 & 4 & 4 & 4 & 4 & 4 \\
\hline Plant life & Years & 40 & 40 & 40 & 40 & 60 & 60 \\
\hline Water cost & $\$ / \mathrm{m}^{3}$ & 0.76 & 0.6271 & 0.89 & 0.7198 & 1.04 & 0.9450 \\
\hline
\end{tabular}

All the results are preliminary in nature which will be used to get an idea about what types of nuclear power plants we should consider according to working conditions of KSA and which desalination technology can be the best option to couple with nuclear power plants. Based on the previous results, it was suggested to opt for small modular nuclear reactors and combine desalination technologies to get the most optimized nuclear desalination option.

\section{Conclusions}

The study concluded the up-to-date information about the implementation and planning of integrated nuclear reactors and desalination systems. Sufficient points of observation to assess the social, environmental, and economic impacts show that siting, re-location, social growth, coastal line, fisheries, and public health and perception are the main points to consider. The review study reveals that more and deeper work not only relating to the technical aspects of nuclear desalination but also other aspects, such as social and environmental, should be considered. Preliminary assessment of cost analysis of nuclear desalination using various combinations of water-purification technologies has been conducted. The economic assessment suggests that either the membrane or the hybrid membrane with thermal energy can be considered as the ideal choice for nuclear desalination.

Author Contributions: Conceptualization, S.U.-D.K. and J.O.; methodology, S.U.-D.K.; software, Khan, S.U.-D.K.; validation, S.U.-D.K. and J.O.; formal analysis, J.O.; investigation, S.U.-D.K.; resources, S.U.-D.K.; data curation, S.U.-D.K. and J.O.; writing-original draft preparation, S.U.-D.K.; writing-review and editing, S.U.-D.K. and J.O.; visualization J.O.; supervision, S.U.-D.K.; project administration, J.O; funding acquisition, S.U.-D.K. All authors have read and agreed to the published version of the manuscript.

Funding: This research was funded by National Plan for Science, Technology and Innovation (MAARIFAH), King Abdulaziz City for Science and Technology, grant number 2-17-02-001-0056.

Institutional Review Board Statement: Not applicable. 
Informed Consent Statement: Not applicable.

Data Availability Statement: Data sharing not applicable.

Acknowledgments: We would like to thanks anonymous reviewers for their constructive comments and suggestions.

Conflicts of Interest: The authors declare no conflict of interest.

\section{References}

1. World Nuclear Association. World Nuclear Performance Report 2020; World Nuclear Association: London, UK, 2020.

2. Desalination, World Nuclear Association, March 2020. Available online: https://world-nuclear.org/information-library/nonpower-nuclear-applications/industry/nuclear-desalination.aspx (accessed on 10 October 2020).

3. IAEA. Toolkit on Nuclear Desalination: DEEP 5 User Manual; IAEA: Vienna, Austria, 2013.

4. IAEA. Toolkit on Nuclear Desalination: DE-TOP User Manual Version 2.0 Beta; IAEA: Vienna, Austria, 2013.

5. Kim, H.S.; No, H.C. Thermal coupling of HTGRs and MED desalination plants, and its performance and cost analysis for nuclear desalination. Desalination 2012, 303, 17-22. [CrossRef]

6. Mansouri, N.Y.; Ghoniem, A.F. Does nuclear desalination make sense for Saudi Arabia? Desalination 2017, 406, 37-43. [CrossRef]

7. Al-Othman, A.; Darwish, N.N.; Qasim, M.; Tawalbeh, M.; Darwish, N.A.; Hilal, N. Nuclear desalination: A state-of-the-art review. Desalination 2019, 457, 39-61. [CrossRef]

8. Li, J.; Sun, H.; Ye, X.; Gao, S.; Yang, J. Economic evaluation of 20,000 M³ / Day seawater desalination coupling with floating reactor nuclear power plant. In IOP Conference Series: Earth and Environmental Science; IOP Publishing: Bristol, UK, 2019; Volume 300, p. 042053.

9. Dong, Z.; Liu, M.; Huang, X.; Zhang, Y.; Zhang, Z.; Dong, Y. Dynamical modeling and simulation analysis of a nuclear desalination plant based on the MED-TVC process. Desalination 2019, 456, 121-135. [CrossRef]

10. Saadooni, J. Desalination option in the Tunisia Nuclear Power Project. In Proceedings of the 16th INPRO Dialogue Forum on Opportunities and Issues in Non-Electric Applications of Nuclear Energy, Vienna, Austria, 12-14 December 2018.

11. Meftah, B. Outlook of Nuclear Energy in Algeria; IAEA-CN-164-1S02; IAEA: Vienna, Austria, 2009.

12. Misra, B.M. Seawater desalination using nuclear heat/electricity_Prospects and challenges. Desalination 2007, 205, 269-278. [CrossRef]

13. Wu, S.; Dong, D. Seawater desalination plant using nuclear heating reactor coupled with MED process. Nucl. Sci. Tech. 2000, $11,6-12$.

14. Wu, S.; Zhang, Z. An approach to improve the economy of desalination plants with a nuclear heating reactor by coupling with hybrid technologies. Desalination 2003, 155, 179-185. [CrossRef]

15. Misra, B.M.; Kupitz, J. The role of nuclear desalination in meeting the potable water needs in water scarce areas in the next decades. Desalination 2004, 166, 1-9. [CrossRef]

16. Khan, S.U.D. Karachi Nuclear Power Plant (KANUPP): As Case Study for Techno-Economic Assessment of Nuclear Power Coupled with Water Desalination. Energy 2017, 127, 372-380. [CrossRef]

17. Karameldin, A.; Shamlou, M.M.; Shaalan, M.R.; Esawy, M.H. Dynamic of reverse osmosis in a standalone co-generative nuclear reactor Part I: Reactivity changes. Int. J. Nucl. Desalin. 2007, 3, 219-233. [CrossRef]

18. Yung, Y.H.; Choi, J.; Wibisono, A.F.; Lee, J.I.; No, H.C. Feasibility study of a small-sized nuclear heat-only plant dedicated to desalination in the UAE. Desalination 2014, 337, 83-97.

19. Aljohani, M.S. Nuclear desalination competitiveness in the western region of the Kingdom of Saudi Arabia. Desalination 2014, 164, 213-223. [CrossRef]

20. Fried, J.J.; Edlund, M.C. Desalting Technology for Middle Eastern Agriculture, An Economic Case; Pracger Publishers: New York, NY, USA, 1971.

21. Abdul-Fattah, A.F.; Husseiny, A.A.; Sabri, Z.A. Nuclear desalination for Saudi Arabia: An appraisal. Desalination 1978, 25, 163-185. [CrossRef]

22. Belessiotis, V.; Papanicolaou, E.; Delyannis, E. Nuclear desalination: A review on past and present. Desalination Water Treat. 2010, 20, 45-50. [CrossRef]

23. Liponi, A.; Wieland, C.; Baccioli, A. Multi-effect distillation plants for small-scale seawater desalination: Thermodynamic and economic improvement. Energy Convers. Manag. 2020, 205, 112337. [CrossRef]

24. Nisan, S.; Caruso, G.; Humphries, J.R.; Mini, G.; Naviglio, A.; Bielak, B.; Alonso, O.A.; Martins, N.; Volpi, L. Sea-water desalination with nuclear and other energy sources: The EURODESAL project. Nucl. Eng. Des. 2003, 221, 251-275. [CrossRef]

25. Competitiveness and Sustainability, Desalination in Nuclear Power Plants; Elsevier Science: Amsterdam, The Netherlands, 2020. [CrossRef]

26. Annual Report SWCC. 2014. Available online: www.swcc.gov.sa (accessed on 10 October 2020).

27. Desalination Plant Inaugurated in Pakistan, Water World, 2011. Available online: https://www.waterworld.com/technologies/ article/16215892/desalination-plant-inaugurated-in-pakistan (accessed on 19 October 2020).

28. Hamoda, M.F. Desalination and water resource management in Kuwait. Desalination 2001, 138, 385-393. [CrossRef]

29. Egypt Nuclear Power Plant Authority (NPPA). Available online: www.nppa.gov.eg (accessed on 19 October 2020). 
30. Kuwaiti Government entities, Az-Zour North Gas-Fired Combined Cycle Power Plant, Hyundai Heavy Industries (HHI) Az-Zour, Kuwait, November 2016. Available online: https:/ / www.power-technology.com/projects/az-zour-north-gas-fired-combinedcycle-power-plant/ (accessed on 19 October 2020).

31. Miri, R.; Chouikhi, A. Ecotoxicological marine impacts from seawater desalination plants. Desalination 2005, 182, 403-410. [CrossRef]

32. California Coastal Commission. Seawater Desalination and the California Coastal Act, Staff Report. Available online: http: / / www.coastal.ca.gov/ energy/14a-3-2004-desalination.pdf (accessed on 9 November 2020).

33. International Atomic Energy Agency. Potential for Nuclear Desalination as a Source of Low-Cost Potable Water in North Africa; IAEA-TECDOC-917; IAEA: Vienna, Austria, 1996.

34. United Nations Environment Programme/Mediterranean Action Plan. Sea Water Desalination in the Mediterranean, Assessment and Guidelines; UNEP/MAP: Athens, Greece, 2003.

35. Elhadj, E. Saudi Arabia's Agricultural Project: From Dust to Dust, Meria, 2008. Available online: http://www.meriajournal.com/ en/asp/journal/2008/june/elhadj/index.asp (accessed on 11 December 2020).

36. Megahed, M.M. An overview of nuclear desalination: History and challenges. Int. J. Nucl. Desalination 2003, 11, 2-18. [CrossRef]

37. Lidsky, L.M.; Miller, M.M. Nuclear Power and Energy Security. A revised Strategy for Japan. Sci. Glob. Secur. 2002, 10, 127-150. [CrossRef]

38. Kavvadias, K.C.; Khamis, I. The IAEA DEEP desalination economic model: A critical review. Desalination 2010, $257,150-157$. [CrossRef]

39. Khan, S.U.-D.; Khan, S.U.-D.; Haider, S.; El-Leathy, A.; AliRana, U.; Danish, S.N.; Ullah, R. Development and techno-economic analysis of small modular nuclear reactor and desalination system across Middle East and North Africa region. Desalination 2017, 406, 51-59. [CrossRef]

40. IAEA-TECDOC-1561. Economics of Nuclear Desalination: New Developments and Site-Specific Studies; Final Results of a Coordinated Research Project 2002-2006; IAEA: Vienna, Austria, 2007. 